Yıldız, D., Kılıç, M, Y. ve Yavuz, M. (2018). “Öğretmenlerin iletişim becerilerini değerlendirme ölçeği” geliştirme çalışması. Ana Dili Eğitimi Dergisi, 6(1), 48-67.

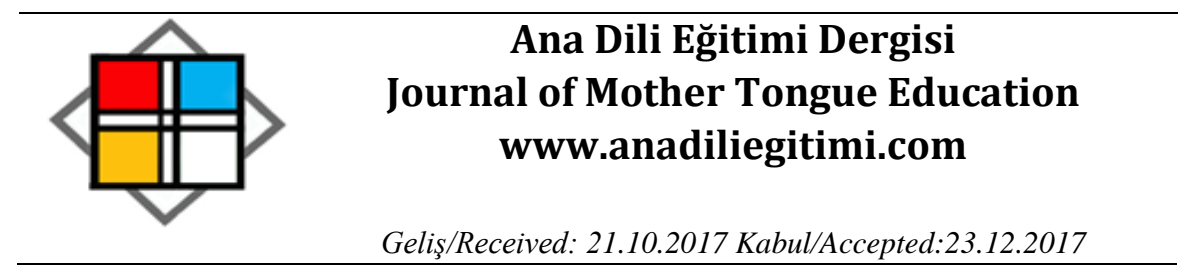

\title{
“Öğretmenlerin İletişim Becerilerini Değerlendirme Ölçeği” Geliştirme Çalışması
}

\author{
Derya YILDIZ* \\ Mehmet Yaşar KILIÇ⿻* \\ Mustafa YAVUZ ${ }^{* * *}$
}

Öz

Bu çalışma ile öğretmenlerin iletişim becerilerini ölçebilecek geçerli ve güvenilir bir ölçme aracı geliştirme amaçlanmıştır. 2016-2017 eğitim-öğretim yılında Konya merkezde ilköğretim ve ortaöğretimde öğrenim gören öğrenciler araştırmanın evrenini oluşturmaktadır. Araştırmada tesadüfi örnekleme yöntemiyle seçilen toplam 259 öğrenciye ölçek uygulanmıştır. Öğrencilerin bir önceki dersi işleyen öğretmenlerinin iletişim becerilerini değerlendirmeleri ile ölçek uygulaması yapılmıştır. Ilgili alan yazın taranarak hazırlanan ölçek maddelerinin son hâli uzman görüşleri neticesinde oluşturulmuştur. Geçerlik ve güvenirlik analizleri neticesinde ilk hâli 73 maddeden oluşan ölçek 20 maddeye indirilmiştir. Maddelerin 12 tanesi olumlu 8 tanesi olumsuz yargıdan oluşmaktadır. Ölçeğin olumsuz yargı içeren maddeleri ters puanlanmaktadır. Açımlayıcı ve doğrulayıcı faktör analizleri ölçeğin geçerliğini sağlamak amacıyla yapılmıştır. Cronbach $\alpha$, Spearman Brown, Gutmann Split-Half teknikleri, düzeltilmiş madde toplam korelasyonları ve \%27'lik alt-üst grup farkına ilişkin $t$ değerler ise ölçeğin güvenirliğini hesaplamada kullanılmıştır. Yapılan analizler geliştirilen ölçeğin geçerli ve güvenilir olduğunu göstermiştir.

Anahtar Kelimeler: İletişim Becerisi, İletişim Becerisi Değerlendirme, Öğretmenler, Geçerlik, Güvenirlik.

\section{The "Teachers' Communication Skills Assessment Scale" Development Study}

\begin{abstract}
The purpose of this study is to develop a reliable and valid assessment instrument in order to measure the communication skills of teachers. The population of the research consisted of students who were studying at the primary and secondary schools in the central district of Konya in the 2016-2017 academic year. The scale was administered to a total of 259 students who were selected, using the random sampling method. The administration of the scale was done by obtaining the students' evaluation of the communication skills of their teachers who taught the previous lesson. The final form of the scale items, which were prepared, using relevant literature, was given by receiving expert opinions. Based on the validity and reliability analyses, the initial 73 items in the scale was reduced to 20 . Of those, 12 sought positive judgments and 8 sought negative judgments. The items that sought negative judgments were graded adversely. Exploratory and confirmatory factor analyses were conducted for the validity of the scale; Cronbach $\alpha$, Spearman Brown, Gutmann Split-Half techniques, and $t$ values related to the bottom
\end{abstract}

\footnotetext{
*Doç. Dr., N.E. Üniversitesi, Konya, dcyildiz@konya.edu.tr

** Bilim Uzmanı, Sivas, myasarkilic@hotmail.com

*** Prof, Dr., N.E. Üniversitesi, Konya, mustafayavuz@konya.edu.tr
} 
and top $27 \%$ groups' differences and corrected item total correlations were calculated for the reliability of the scale. The results of the analyses showed that the scale was valid and reliable.

Keywords: Communication Skill, Communication Skill Evaluation, Teachers, Validity, Reliability.

\section{Giriş}

Sosyal bir varlık olarak insan çevresiyle sürekli etkileşim halindedir. Bireyin kendisini çevresine daha iyi ifade edebilmesi ve karşısındakinin söylediklerini daha iyi anlayıp yorumlayabilmesi için etkili konuşma ve dinleme becerilerini kazanmış olması gerekmektedir. Öğretmenlik gibi sürekli öğrencileriyle etkileşim halinde bulunulması gereken meslekler için bu becerilerin elde edilmesi daha çok önem arz etmektedir. Bu becerilere ise "iletişim becerileri" denilmektedir.

İletişim, Latince kökenli bir kavramdır. Düşüncelerin paylaşılması anlamına gelen "communis" kelimesinden türetilmiştir (Debasish ve Das, 2009; Zıllığlu, 1993). İletişim temel anlamda birtakım sembol ve işaretler kullanarak karşısındakini etkileme süreci olarak görülmektedir (Dökmen, 1997). Yılmaz ve Tutar (2003) iletişimi; bilgi üretme, üretilen bilgiyi karşısındakine iletme ve karşıdakinin bilgiyi algılama süreci olarak tanımlamaktadır. Iletişimin sağlıklı bir şekilde gerçekleştirilebilmesi için ise bireylerin etkili iletişim becerilerine sahip olması gerekmektedir. Bıçakçı'ya (2003) göre bu becerileri kazanan birey, karşısındakinin duygu, düşünce ve isteklerini anlayan, bunların sebeplerini ve kaynaklarını değerlendirme yeteneği olan kişidir. İletişim yeteneği içerisinde empati ve saygıyı barındıran bir kavram olmakla birlikte duygu ve düşüncelerin karşısındakilere doğru ve eksiksiz bir şekilde ben dili ile aktarılmayı sağlayan ve böylece sağlıklı ilişkiler kurarak toplum içerisinde yaşamı kolaylaştırabilen davranışlar olduğu ifade edilmiştir (Şahin, 1998).

Öğretmenlik mesleğinde başarılı olma, bireylerin sahip olduğu iletişim becerilerini etkin bir şekilde kullanabilmelerini gerektirir (Balcı, 1996).Öğretmenlerin bilgi ve becerilerini kullanabilme düzeyleri eğitimin etkililiğini belirlemektedir. İletişim becerisi yüksek olan öğretmenler öğrenme ortamlarında bilgi ve becerilerini etkili olarak sunabilmektedirler. Bu bağlamda öğretmenlerin eğitimöğretim faaliyetlerini etkili bir şekilde gerçekleştirebilmesi için kendilerini sürekli olarak geliştirmesi gerekmektedir. Ayrıca çevresiyle sürekli etkileşim halinde bulunan öğretmenlerin kendini ifade edebilmesi ve söylenenleri daha iyi anlayabilmesi eğitimin etkililiğini artıracaktır.

Sönmez (2003), eğitim-öğretim sürecinin gerçekleştirilmesinde başrol oynayan öğretmenlerin, sürekli olarak öğrencilerle etkileşim halinde bulunan kişi olduğunu belirtir. Bu etkileşim öğretmen ve öğrenciler arasında etkili bir iletişim ortamını gerekli kılar. Illetişimi bilgi üretme, üretilen bilgiyi aktarma ve bilginin anlamlandırılması süreci (Dökmen, 1997) olarak tanımlarsak, eğitim de genel olarak bir iletişim süreci olarak görülebilir. Öğrenci ve öğretmen arasındaki etkileşim, iletişim vasıtasıyla gerçekleşmektedir. 
Öğrenme ortamlarında başarıya ulaşmak için sadece öğretmen-öğrenci iletişimi değil veli, okul yöneticileri ve çalışanları yani bütün eğitim paydaşları arasında da etkili bir iletişim olmalıdır (Küçükahmet vd., 2000). Ancak öğrenme ortamlarında öğrenci ve eğitimin diğer paydaşları ile öğretmenlerin doğrudan etkileşim içinde olması, öğretmenlerin iletişim bakımından donanımlı olmasını gerekli kılmaktadır.

Alan yazında yapılan araştırmalarda (Claus, Booth-Butterfield ve Chory, 2012; Güçlü, 2001), öğretmenlerin öğrencileri ile kurduğu iletişimin seviyesinin, öğrencilerin derse katılımını, ders çalışma isteğini ve başarısını doğrudan etkilediği tespit edilmiştir. Ayrıca yapılan birçok araştırmaya göre de (Baker, 2006; Hallinan, 2008; O'Connor ve McCartney, 2007) öğretmenlerin iletişim becerisi ile öğrencilerin akademik başarısının pozitif yönlü ilişkili olduğu belirlenmiştir.

Alan yazın incelendiğinde genel olarak iletişim becerileri arasında, etkin dinleme ve konuşma, kendi bilgi ve becerilerini iyi tanıma, karşıdakini ikna etme ve etkileme, empati becerisine sahip olma, kendisine ve karşıdakine güven ve saygı duyma, karşısındakine kendisini açma, ben dilini etkili bir şekilde kullanma ve geri bildirimlerde bulunma becerileri bulunmaktadır (McKay, M., vd, 2012; Gürüz ve Eğinli, 2013). Gibson ve Mitchell'e (1995) göre ise iletişim becerileri, etkili dinleme ve tepki verme, sözel ve sözel olmayan mesajlara duyarlılık duyarlı olma özelliklerini kapsamaktadır. Baker ve Shaw’a (1987) göre ise iletişim becerileri, sözel ve sözel olmayan mesajlara duyarlı olma, etkili dinleme, konuşma ve olaylara etkili tepki verme davranışları olarak görülmektedir. Alan yazın incelendiğinde etkili iletişim becerileriyle ilgili birçok davranış tanımları olmasına rağmen ortak bir fikir birliği sağlanamamıştır.

Illetişim becerilerini ölçmek amacıyla yapılmış olan çalışmalara baktığımızda birçok ölçeğin kullanıldığını görmekteyiz. Owen ve Bugay (2014) tarafından geliştirilen ölçekte iletişim becerilerinin dört boyutu üzerinde durulmuştur. Bu beceriler, iletişim ilkeleri ve temel iletişim becerisi, kendini ifade etme becerisi, etkin dinleme ve sözel olmayan iletişim becerisi ve iletişim kurmaya istekliliktir. Diğer bir ölçek ise Wiemann (1977) tarafından geliştirilen ve Topluer (2008) tarafından Türkçeye çevrilen iletişim becerileri ölçeğidir. Bu ölçekte ise iletişim becerilerinin anlama-empati kurabilme, sosyal rahatlık ve destekleme boyutu üzerinde durulmuştur. Şimşek (2003) tarafından geliştirilen ölçekte iletişim becerilerinin 17 alt boyutu üzerinde durulmuştur. Bunlar arasında, empati kurma, dinleme becerisi, tutumlar, bilgi düzeyi ve bilgilendirme gibi kavramlar vardır. Diğer bir ölçek ise Ersanlı ve Balcı'nın (1998) geliştirdiği iletişim becerileri ölçeğidir. Bu ölçekte, iletişim becerilerinin davranışsal, bilişsel ve duygusal olmak üzere üç boyutu üzerinde durulmuştur.

Empati ve Yardım Becerileri: Empati bir olay veya bir durum karşısında bireyin kendisini karşısındakinin yerine koyarak onun içinde bulunduğu duygu ve düşünceleri anlamak olarak 
tanımlanabilir (Dökmen 1997). Hogan (1969) ise empatiyi bireyin karşısındakinin durumunu kendi zihinsel olanaklarıyla anlayarak, o kişinin sahip olduğu duygu ve düşünceleri birebir yaşamadan ne hissettiğini anlamak olarak tanımlamıştır. Yani empati karşısındaki bireyin duygularını yaşama değil de onun duygularını anlamak ile ilgili bir kavramıdır (Badea ve Pana 2010). Bu tanımlara baktığımızda insan ilişkilerinin en yoğun şekilde yaşanıldığı okullarımızda empati önemli bir kavram olarak görülmektedir. Pala'ya (2008) göre öğretmenlerin en önemli rollerinden birisi, öğrencilerle etkili bir iletişim kurabilmek için onlarla empatik ilişkiler geliştirerek onların bireysel dünyalarına girmek ve bu sayede güvenli ve olumlu bir sınıf ortamı oluşturmaktır. Empati becerisine sahip olamayan öğretmenler öğrencilerin sahip olduğu duyguları ihmal ederek ve sadece eğitim programlarına yoğunlaşarak aslında onların motivasyonlarının kaybolmasına neden olmaktadırlar (Cooper, 2002).

Yardım etme davranışına baktığımızda, bireyin bir zorunluluğu olmadan ya da herhangi bir görevi olmamasına rağmen diğer bireylerin görevlerini istekli olarak yapma davranışlarıdır (George ve Jones, 1997; ; Podsakoff, Mackenzie, Paine ve Bachrach, 1990). Sınıf içerisinde veya sosyal yaşamda öğretmenlerin yardım etme davranışı göstermeleri öğrencileriyle olan iletişimlerinde güçlendirici bir etki yaratacaktır. Bu şekilde iletişim kurulduğunda öğrencilerin motivasyonunun artması ve böylece de sınıf içi ve sosyal başarılarının da artması beklenen bir durumdur. Empati yeteneği, yapıcı konuşmalar, etkili geri bildirimler, iyi bir dinleyici ve yardımseverlik ile demokratik bir sınıf ortamı oluşturma öğretmenlerin etkili iletişim kurmasında önemlidir.

İletişim Ortamı Oluşturma: Öğrencinin sınıf içerisindeki konumu ve sınıf ortamının yapısı ile ilgili çalışmalar 1960’lardan beri önem kazanarak günümüze kadar gelmiştir (Özgüven, 1994). Yapılan araştırmalarda öğretmen-öğrenci iletişimlerinin pozitif yönde olması ve sınıf ortamında oluşturulan destekleyici yapı, öğrencilerin istenilen davranışları sergilemeleri ve psikolojik gereksinimlerini sağlamaları açısından önemli görülmektedir (Celep, 1997). Bu konuda öğretmenlere büyük bir görev düşmektedir. Çünkü sınıfta iletişimin en önemli ögesi öğretmenlerdir. Sınıf ortamında öğretmen ve öğrenci ilişkisinin niteliği öğrenci başarısını etkilemektedir. Aşkar’a (1995) göre bir öğretmen öğrencilerini tek tek tanıyabilmeli, öğrencinin etkili bir şekilde nasıl öğreneceğini bilmeli ve bu bilgi doğrultusunda öğrencilerine farklı öğrenme ortamları sunabilmelidir. Öğretmenin öğrencilerini tanıyabilmesi için sınıfta etkili bir iletişim ortamı kurması gereklidir. Sınıf içerisinde etkili bir iletişim ortamı kurabilmek için; a- öğretmenin konuşma yeteneğini geliştirmesi, b- öğrencilerin ilgi ve yeteneklerinin tespit edilip değerlendirmesi, c- dersin iyi bir şekilde planlanması, $d$ - derste öğrencilere de sık sık söz hakkı verilmesi, e- öğrencilerin dikkatini dağıtacak anlatımdan kaçınılması gerekmektedir (Demirel, 1995). Öğretmenin sınıf içerisinde kendisini eğitim ve öğretimin tek hâkimi olarak görmesi tek yönlü iletişim ortaya çıkmasına neden olmaktadır. Etkili bir iletişim ortamı oluşturmak isteyen öğretmeninin öğrencilere düşüncelerini ifade edebileceği bir ortam sağlaması, 
derse katılması için fırsatlar yaratması, öğrencilerini sevmesi ve onlarla göz teması kurması ve eleştiriye açık olması gerekmektedir. Böylece etkili iletişim ortamı yaratılmış olur.

Sınıf Yönetimi: Etkili bir sınıf yönetiminde en önemli unsurlardan biri etkili iletişimdir. Öğretmen sınıf yönetiminde başarılı olmak istiyorsa sınıf içi iletişimi iyi koordine etmelidir. Sınıfta etkili bir iletişimin kurulması sonucunda sınıf içi sorunların tespit edilmesi ve büyümeden çözülmesi, öğrencilerin ilgi ve yeteneklerinin tespit edilmesi, sınıfta bilgi akışının yüksek seviyede olması, öğrencilerin daha iyi tanınması, öğrencilerin beklentilerinin tam olarak belirlenmesi sağlanabilmektedir (Celep, 2002; Gürsel 2011). Engin ve Aydın’a (2007) göre öğretmen öğrencilerini iletişime teşvik etmeli ve bu yönde mesajlar vermelidir. Dersi eğlenceli hale getiren, hoşgörülü ve gülümseyen öğretmen doğal olarak öğrencileriyle daha etkili iletişim kuracaktır. Böylece öğrenciler kendilerini sınıfta daha rahat hissedecek ve böylece derse katılımları artacaktır. Fakat somurtkan, öğrenciyle iletişim kurmaktan imtina eden ve onu dinlemeyen öğretmen öğrenciyi dersten soyutlamakta ve tek yönlü bir iletişim kurmaktadır. Bu durum da eğitimin etkililiği düşürdüğü için büyün sorun oluşturmaktadır. Celep'e (2002) göre öğrenciler, samimi ve kendileriyle arkadaş olan öğretmenleri tercih etmektedirler. Öğrencilerle iletişimi üst düzeyde olan öğretmenler, öğrencilerin okula karşı daha olumlu yargılar taşımalarını sağlayacaktır. Aksi takdirde ders boyunca masada oturan, dersi kendi kendine anlatan, sınıfta gürültü olduğunda nasıl davranacağını bilemeyen, derse ilgisiz olanları umursamayan yani öğrencilerle iletişim kuramayan öğretmen, öğrencileri istenilen davranışı sergilemesi yönünde motive edemeyecektir.

İletişim Engelleri: Iletişim sürecinde, bir iletinin aktarılmasını ve karşı tarafın almasını engelleyen tüm faktörlere iletişim engelleri denilmektedir (Ergin ve Birol, 2000). Gordon' a (1998) göre iletişim engellerine sebep olan bazı durumlar bulunmaktadır. Bu durumlar sınıf içerisinde tek yönlü iletişimin oluşmasına sebep olmaktadır. Bunlar;

“ 1. Emir vermek - yönlendirmek, 2. Uyarmak, gözdağı vermek, 3. Ahlak dersi vermek, 4. Ögü̈t vermek, çözüm ve öneri getirmek, 5. Öğretmek, nutuk çekmek, mantıklı düşünceler önermek, 6. Yargılamak, eleştirmek, suçlamak, 7. Ad takmak, alay etmek, 8. Yorumlamak, analiz etmek, 9. Övmek, aynı düşüncede olmak, olumlu değerlendirme yapmak, 10. Güven vermek, desteklemek, avutmak, duygularını paylaşmak, 11. Soru sormak, sınamak, sorguya çekmek, çapraz sorgulamak, 12. Sözünden dönmek, oyalamak, alay etmek, şakacı davranmak, konuyu saptırmak" dır.

Pollard’a (2006) göre öğrenciler öğretmenleri tarafından tembel, terbiyesiz veya beceriksiz gibi sıfatlarla anılmak istemezler. Bu tür sıfatlar sınıf içerisinde öğrencilerde iletişim engeli yaratır ve öğrencilerin çekingen, özgüvensiz bir birey haline gelmesine sebep olur. İletişimin fonksiyonlarının farkında olan bir öğretmen sınıf içerisinde öğrencilerini cesaretlendirmeli, öğrencilerin doğruya 
ulaşmaları için onlara yol göstermelidirler. Öğretmenlerin sınıf içerisinde yargılayıcı ve emredici bir tavırda olmaları, öğrenciler yanlış yaptıklarında onlara kızmaları ve başarısız öğrencileri sevmemeleri iletişim engellerini oluşturmaktadır.

Bu çalışma ile alan yazında doğrudan öğretmenlerin iletişim becerilerini ölçen bir ölçeğin bulunmamasından hareketle "öğretmen iletişim becerisi değerlendirme ölçeği” geliştirilmesi amaçlanmıştır. Bu ölçek aracılığıyla öğretmenlerin sahip oldukları iletişim beceri düzeyinin belirlenerek tespit edilen eksik yönlerin geliştirilmeye çalışılması öğretmenlerin daha iyi iletişim becerilerine sahip olmalarında önem taşımaktadır.

\section{Yöntem}

\section{Evren ve Örneklem}

Araştırmanın evrenini 2016-2017 eğitim-öğretim yılında Konya merkezde ilköğretim ve ortaöğretimde öğrenim gören öğrenciler oluşturmaktadır. Bu araştırmada tesadüfi örnekleme yöntemiyle seçilen toplam 300 öğrenciye ölçek uygulaması yapılması plânlanmıştır. İncelemeler yapıldıktan sonra geri dönen ölçeklerin $259^{\prime} u$ analiz için uygun bulunmuştur.

Araştırmaya katılan öğrencilerin \%54,4'ü erkek $(n=141), \% 45,6^{\prime}$ sı kız $(n=118)^{\prime}$ dır. Ayrıca katılımcıların \%25,5'i 5. Sınıfta ( $n=66), \% 24,7^{\prime}$ si 6. Sınıfta ( $\left.n=64\right), \% 21,6$ 'sı 7. sınıfta ( $\left.n=56\right), \% 5^{\prime}, 8$. sınıfta ( $n=13), \% 11,6$ 'sı 9. sınıfta $(n=30), \% 6,2^{\prime}$ si 10. Sınıfta $(n=16)$ ve \% 5,4'ü ise 11. sınıfta $(n=14)$ okumaktadır. Öğrencilerin cevapladıkları ölçekte bir önceki dersi veren öğretmenlerini değerlendirmeleri istenmiştir. Ölçek ilk hâliyle toplam 73 maddeden oluşmaktadır.

\section{Öğretmen İletişim Becerisi Değerlendirme Ölçeğinin Geliştirilme Süreci}

73 maddeden oluşan ölçeğin ilk hâli 259 öğrenciye uygulanmış ve elde edilen veri setine gerekli analizler yapılarak ölçeğe son hali verilmiştir.

Elde edilen ölçek toplam 20 maddeden oluşmaktadır. Bu maddelerin 12 tanesi olumlu 8 tanesi olumsuz yargı içermektedir. Olumsuz yargı içeren maddeler ters puanlanmaktadır. Ölçek $5^{\prime} l i$ likert tipinde oluşturulmuştur. 5-Her Zaman, 1-Hiçbir Zaman şeklinde oluşturulmuştur. Ölçekten en az 20 puan en fazla 100 puan alınabilmektedir.

\section{Bulgular}

Ölçeğin Geçerlik ve Güvenirlik Çalışması

Ö/çeğin Geçerliği

-Kapsam (içerik) Geçerliği 
Kapsam geçerliği, ölçeği oluşturan maddelerin ölçülmek istenilen önceden tanımlanmış davranışlar bütününü ne derecede ölçtüğü ile ilgilidir (Büyüköztürk vd. 2010, s.119). Ölçeğin kapsam geçerliğini sağlamak için uzman görüşüne başvurulmuştur. Oluşturulan madde havuzu uzmanlara gönderilmiş ve sorularla ilgili görüşleri alınmıştır. İkisi Türkçe Eğitiminden biri Eğitim Bilimlerinden olmak üzere toplam üç uzmandan görüş alınmıştır. Uzman görüşlerine göre üç soru madde havuzundan çıkarılmış, iki soru ise tek bir soru altında birleştirilerek ölçeğe son hali verilmiştir.

\section{-Yapı Geçerliği}

Yapı geçerliği ölçekten elde ettiğimiz puanların, ölçek ile ölçülmek istenen yapının gerçekte ne derecede ölçüldüğü ile ilgili bir kavramdır (Büyüköztürk, 2002; Erkuş, 2003). Ölçeğin yapı geçerliğinin belirlenmesi için önce açımlayıcı faktör analizi sonra doğrulayıcı faktör analizi yapılmıştır. Böylece ölçeğin ölçülmek istenen özelliği doğru bir şekilde ölçme kapasitesinin belirlenmesi amaçlanmıştır.

\section{Açımlayıcı Faktör Analizi Sonuçları}

Açımlayıcı faktör analizi yapmadan önce verilerin faktör analizine uygunluğunu belirlemek amacıyla KMO değeri belirlenmiş ve Bartlett Sphericity testi yapılmıştır.

Tablo 1. Ölçeğin Barlett's Test ve Kaiser-Mayer-Olkin (KMO) Örneklem Ölçüm Sonuçları

\begin{tabular}{llll}
\hline $\begin{array}{l}\text { Kaiser-Mayer-Olkin (KMO) Örneklem Ölçüm } \\
\text { Değer Yeterliği }\end{array}$ & 0,922 & & \\
\hline Barlett Testi Yaklaşık Ki-Kare Değeri & 2177,967 & $\mathrm{sd}=190$ & $\mathrm{p}=0,000^{*}$ \\
\hline
\end{tabular}

Yapılan analiz sonuçlarına göre KMO değeri .919 Bartlett Sphericity testi değeri anlamlı bulunmuştur $\left[x^{2}: 2056,767039, p<.000\right]$. Bu sonuçlara göre veriler faktör analizi yapmaya uygun olarak nitelendirilebilir.

Tablo 2. Ölçeğin Alt Boyutlarının Öz Değerleri ve Açıkladıkları Varyans Yüzdeleri

Total Variance Explained

\begin{tabular}{|c|c|c|c|c|c|c|c|c|c|}
\hline \multirow[t]{2}{*}{ Component } & \multicolumn{3}{|c|}{ Initial Eigenvalues } & \multicolumn{3}{|c|}{$\begin{array}{c}\text { Extraction Sums of Squared } \\
\text { Loadings }\end{array}$} & \multicolumn{3}{|c|}{$\begin{array}{c}\text { Rotation Sums of Squared } \\
\text { Loadings }\end{array}$} \\
\hline & Total & $\begin{array}{c}\% \text { of } \\
\text { Variance }\end{array}$ & $\begin{array}{c}\text { Cumulative } \\
\%\end{array}$ & Total & $\begin{array}{c}\% \text { of } \\
\text { Variance }\end{array}$ & $\begin{array}{c}\text { Cumulative } \\
\%\end{array}$ & Total & $\begin{array}{c}\text { \% of } \\
\text { Variance }\end{array}$ & $\begin{array}{c}\text { Cumulative } \\
\%\end{array}$ \\
\hline 1 & 7,758 & 38,788 & 38,788 & 7,758 & 38,788 & 38,788 & 3,651 & 18,257 & 18,257 \\
\hline 2 & 1,674 & 8,368 & 47,157 & 1,674 & 8,368 & 47,157 & 3,222 & 16,112 & 34,369 \\
\hline 3 & 1,267 & 6,335 & 53,491 & 1,267 & 6,335 & 53,491 & 2,505 & 12,526 & 46,895 \\
\hline 4 & 1,090 & 5,450 & 58,942 & 1,090 & 5,450 & 58,942 & 2,409 & 12,047 & 58,942 \\
\hline 5 & ,880 & 4,398 & 63,340 & & & & & & \\
\hline
\end{tabular}




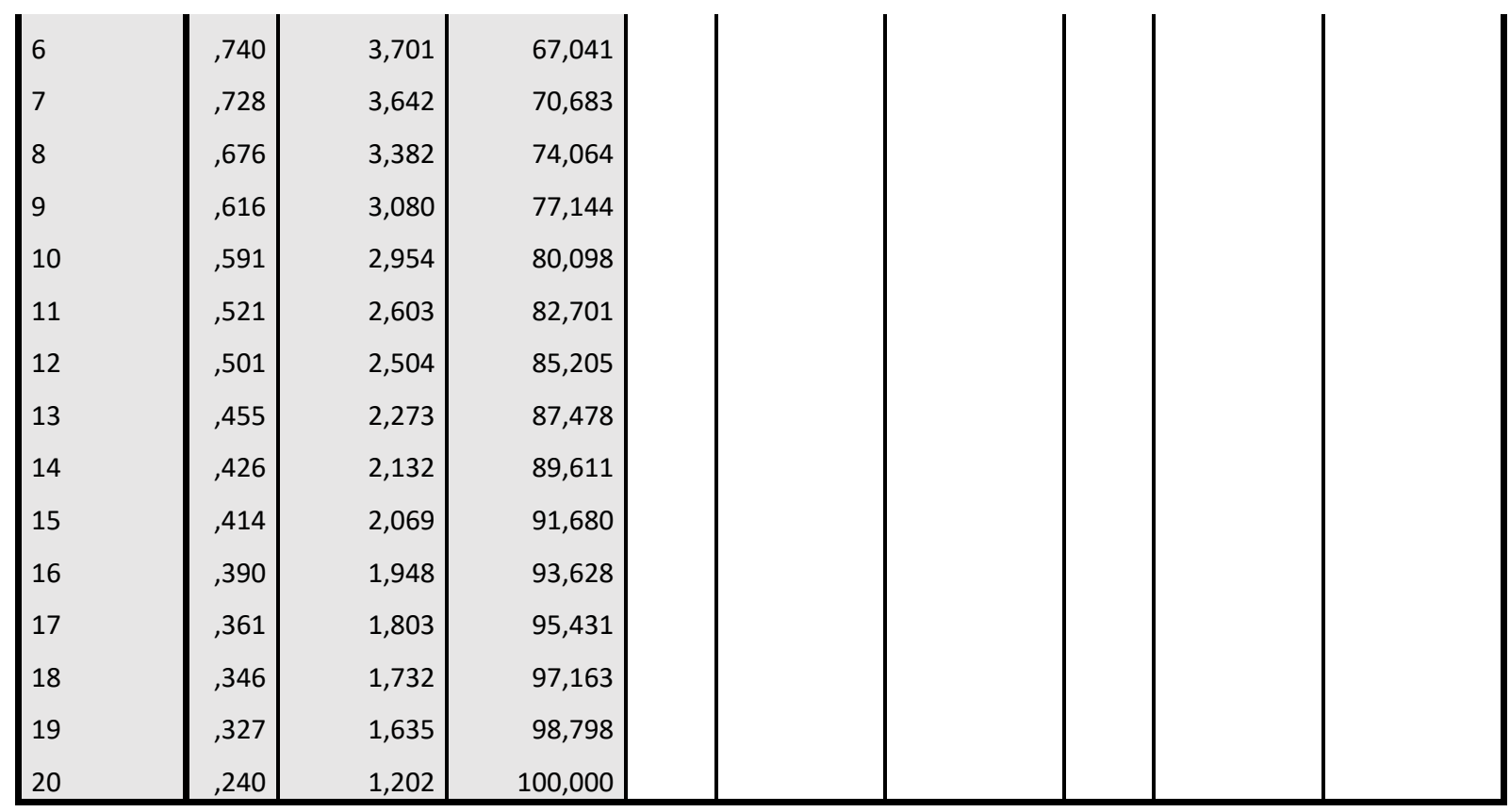

Extraction Method: Principal Component Analysis.

Yapılan analizde varimax döndürme tekniği kullanılmıştır. Açımlayıcı faktör analizi sonucuna göre ölçeğin öz değeri birden büyük dört alt boyuttan oluştuğu görülmektedir. Birinci alt boyut toplam varyansın 18,257 'sini, ikinci alt boyut toplam varyansın 16,112 'sini, üçüncü varyans toplam varyansın 12,526'sını ve dördüncü alt boyut toplam varyansın 12,047'sini açıklamaktadır. Bu dört alt boyut ise ölçekteki toplam varyansın \% 58,942'sini açıklamaktadır.

Tablo 3. Serpilme Diyagramı (Scree Plot)

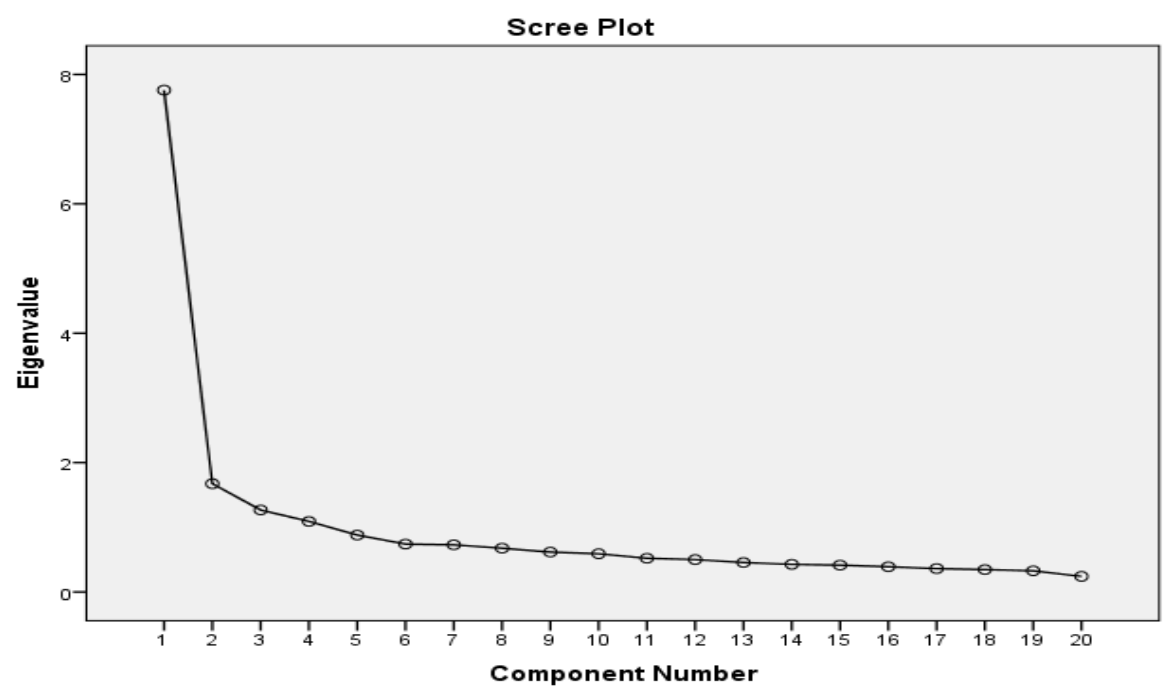

Serpilme diyagramına baktığımızda öz değeri birden büyük olan 4 faktör olduğu görülmektedir. Bundan dolayı ölçeğimiz 4 faktörden oluşmaktadır. Ölçeğin hesaplanan faktör yük değerleri Tablo 4'te verilmiştir. 
Tablo 4. AFA Sonuçları

\begin{tabular}{|c|c|c|c|c|}
\hline \multicolumn{5}{|c|}{ Rotated Component Matrix ${ }^{a}$} \\
\hline & \multicolumn{4}{|c|}{ Component } \\
\hline & 1 & 2 & 3 & 4 \\
\hline s65 & 735 & 171 & 184 & 298 \\
\hline s67 & ,722 & 284 & 151 & 141 \\
\hline s52 & 698 & ,361 & ,027 & 225 \\
\hline s39 & 666 & 201 & 306 & 199 \\
\hline s60 & ,656 & ,312 & 241 & 168 \\
\hline s56 & 634 & 261 & 308 & ,044 \\
\hline s1 & 239 & ,748 & 192 & 115 \\
\hline s3 & 232 & ,680 & 281 & ,097 \\
\hline s5 & 335 & ,677 & ,001 & 169 \\
\hline s15 & ,428 & ,625 & ,052 & 285 \\
\hline s27 & 103 & ,610 & 302 & 151 \\
\hline s13 & 278 & ,515 & 128 & 196 \\
\hline s31 & 159 & 207 & ,769 & ,037 \\
\hline s41 & 246 & ,041 & ,701 & ,035 \\
\hline$s 28$ & 077 & 117 & 680 & ,097 \\
\hline s33 & 202 & 263 & ,630 & 171 \\
\hline s72 & 300 &,- 024 & 127 & 749 \\
\hline$s 63$ & 260 & 188 & ,062 & ,707 \\
\hline s45 & 206 & 239 & ,047 & 681 \\
\hline s11 &,- 022 & ,218 & 101 & ,649 \\
\hline
\end{tabular}

Tabloda görüleceği gibi faktör yük değerleri .515 ve .769 arasında değişmektedir. Bulunan faktör yük değerleri standart değerlerin arasındadır. Sonuçlara göre birinci faktörde 6, ikinci faktörde 6 soru, üçüncü faktörde 4 ve dördüncü faktörde 4 soru bulunmaktadır. Ölçek toplam 20 maddedir.

\section{Doğrulayıcı Faktör Analizi Sonuçları}

Yapılan AFA sonucunda ölçek; "empati ve yardım becerileri” (1. Alt Boyut), "iletişim ortamı oluşturma" (2. Alt Boyut), "sınıf yönetimi" (3. Alt Boyut) ve "iletişim engelleri" (4. Alt Boyut) olmak üzere 4 alt boyuttan oluşmaktadır. "Empati ve yardım becerileri" alt boyutu 6 maddeden, "iletişim ortamı oluşturma" alt boyutu 6 maddeden, "sınıf yönetimi" alt boyutu 4 maddeden ve "iletişim engelleri" alt boyutu 4 maddeden oluşmaktadır.

Alan yazında ölçek geliştirirken ölçeklerin faktör yük değerlerinin .30 ve üzeri kabul edilebileceği belirtilmektedir. Bu çalışmada da ölçek faktör yükünün .30 ve üzerindeki maddeler değerlendirmeye alınacaktır. 
Modelin doğrulayııı faktör analizi Şekil 1'de test edilmiştir.

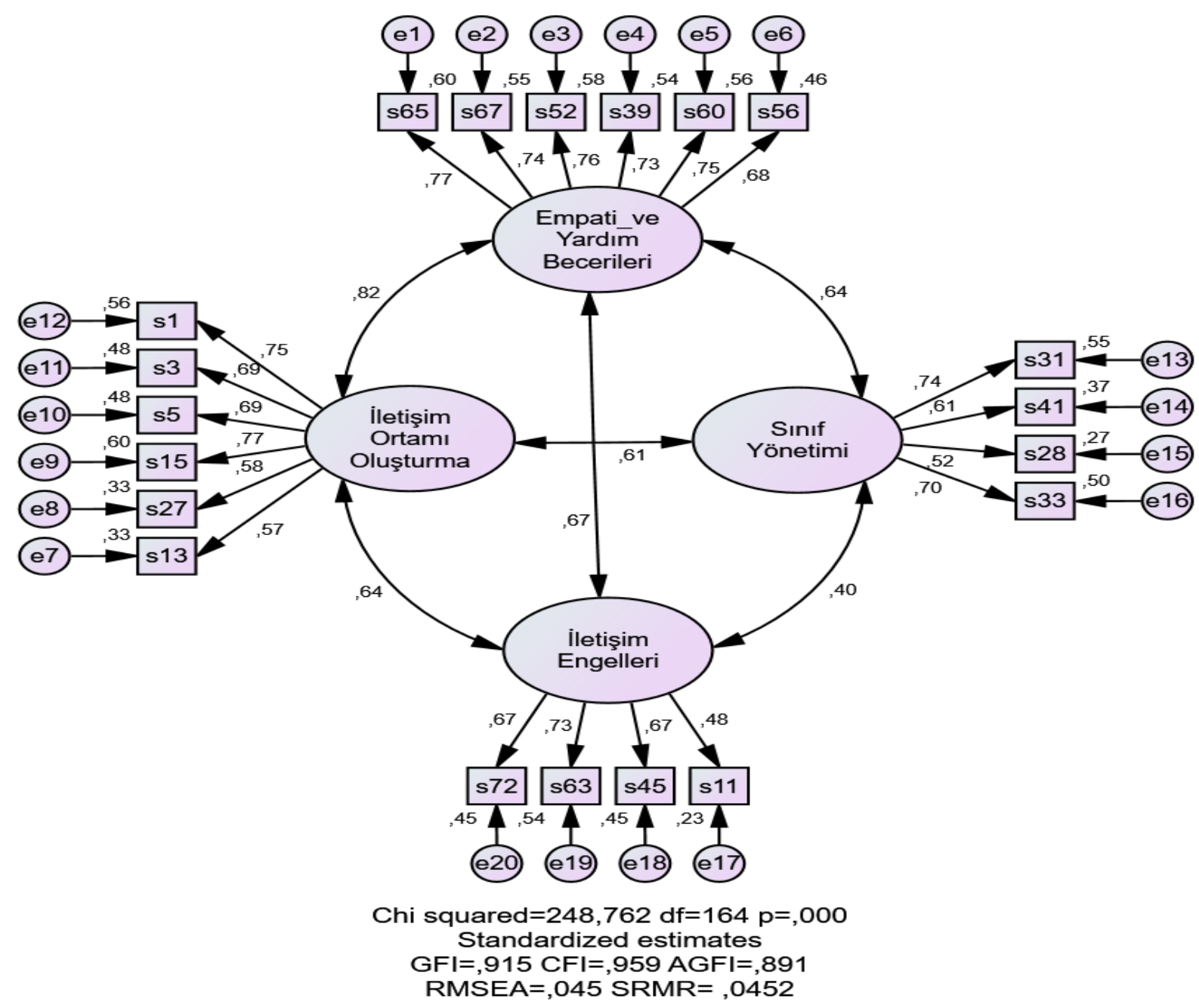

Şekil 1. Birinci Düzey Doğrulayıcı Faktör Analizi Sonuçları

Yukarıdaki birinci düzey uyum iyiliği sonuçlarına baktığımızda ki-kare 248,762 , serbestlik derecesi, 164 ( $p=.00)$, ki-kare/serbestlik derecesi= 1.517, uyum iyiliği indeksi GFI ,915, karşılaştırmalı uyum indeksi CFI .959, düzeltilmiş uyum indeksi AGFI .891, yaklaşık hataların ortalama karekökü RMSEA .45 ve standarize edilmiş kalıntıların ortalama karekökü SRMR .45 olarak bulunmuştur. Genel olarak sonuçlara baktığımızda uyum iyiliklerinin oldukça iyi olduğu görülmektedir. Daha sonra 2. düzey faktör analizi yapılmıştır. 


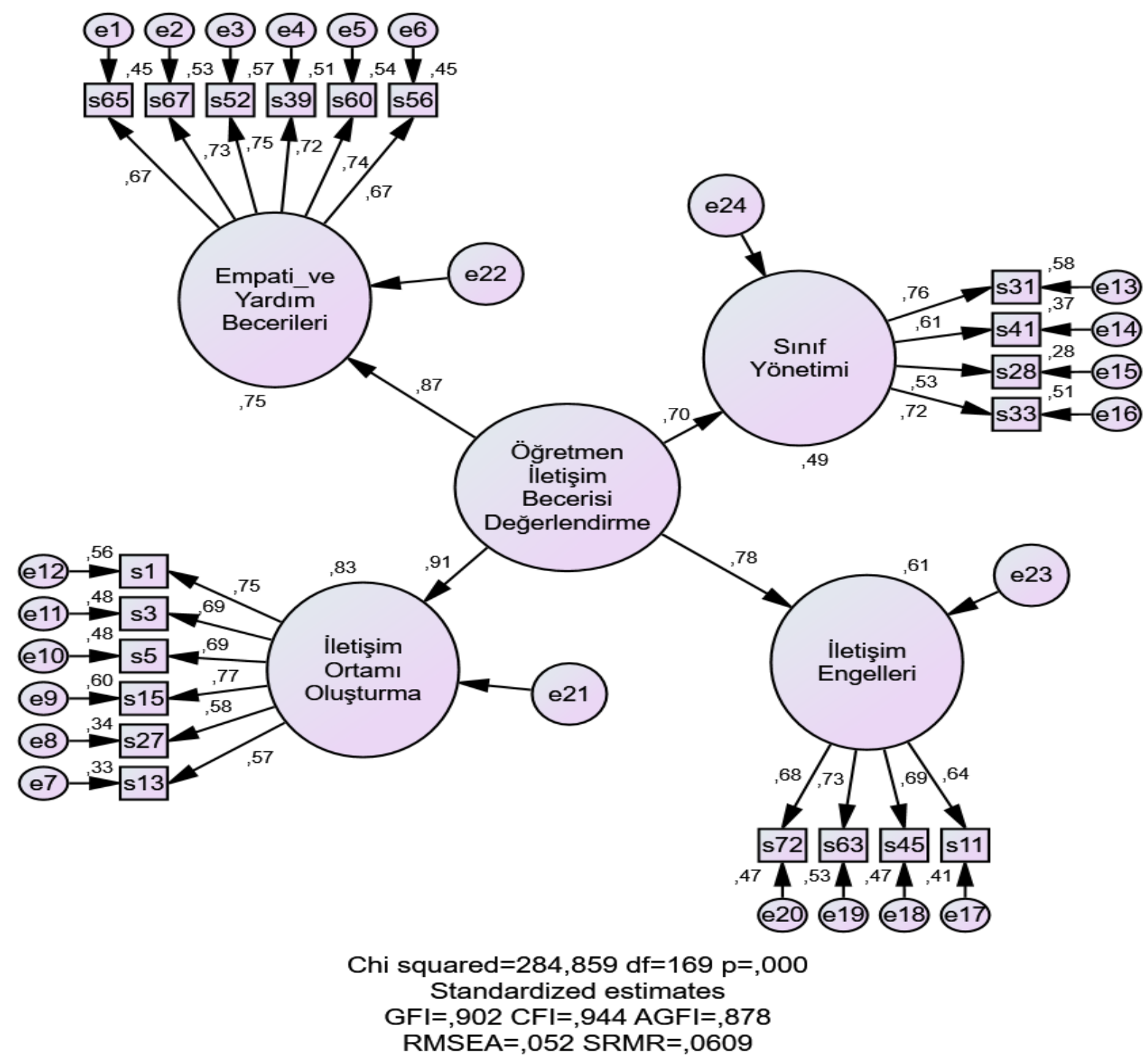

Şekil 2. İkinci Düzey Doğrulayıcı Faktör Analizi Sonuçları

Yukarıdaki ikinci düzey uyum iyiliği sonuçlarına baktığımızda ki-kare, 284,858, serbestlik derecesi 169, $(p=.00), \mathrm{GFI}=.902 \mathrm{CFI}=.944 \mathrm{AGFI}=.878 \mathrm{RMSEA}=.52$ SRMR=.609 olarak bulunmuştur. Bir yapısal eşitlik modelinin uygun olarak kabul görebilmesi için RMSEA değerinin .08 'in altında olması gerekmektedir (Şimşek, 2007). Elde edilen uyum iyiliği değerlerine baktığımızda ise elde edilen değerlerin, iyi uyum iyiliği ve kabul edilebilir uyum iyiliği gösterdiği söylenebilir (Kline, 2016; Bayram, 2013; Baumgartner \& Homburg, 1996).

Ölçeğin Güvenirliği

-iki Yarı Test Güvenirliği 
Ölçeğin güvenirliğini hesaplamak için Spearman Brown ve Guttman Split Half tekniği kullanılmıştır. Yapılan analizler sonucunda Spearman Brown formülüyle hesaplanan iki yarı test güvenirliği .923 ve Guttman Split-Half tekniği kullanılarak yapılan iki yarı test güvenirliği de $.847 \mathrm{Bu}$ değerler, ölçeğin iç tutarlılı̆ının ve iki yarı test güvenirliğinin yüksek olduğunu göstermektedir.

\section{-Cronnbach a Güvenirliği}

Ölçek için ve faktörler için hesaplanan Cronbach $\alpha$ güvenirlik katsayı değerleri Tablo 5'te verilmiştir.

Tablo 5. Alt Ölçeğin ve Ölçeğin Genel Olarak Cronbach Alpha Değeri

\begin{tabular}{|rlc|}
\hline Ölçeğin Boyutları & Cronbach Alpha \\
\hline 1. & Alt Boyut & .875 \\
\hline 2. & Alt Boyut & .819 \\
\hline 3. & Alt Boyut & .734 \\
\hline 4. & Alt Boyut & .736 \\
\hline Toplam Ölçek & .908 \\
\hline
\end{tabular}

Ölçeğin güvenirlik katsayılarına baktığımızda ölçeğin genel güvenirliği .908 olduğu görülmektedir. Bu sonuç ölçeğin oldukça güvenilir olduğunu göstermektedir.

Uygulanan ölçeğin güvenirliğini test etmek için ölçeğin madde toplam korelasyonuna ve toplam puanlarına göre oluşturulan, ölçekten en düşük puan alan ve ölçekten en yüksek puan alan \%27 içinde bulunan katılımcıların toplam puan ortalamaları t testi ile her bir madde için karşılaştırılmıştır. Madde toplam puan korelasyonu ölçek maddelerinden elde edilen puanlar ile toplam alınan puanlar arası ilişkiyi açıklar. Büyüköztürk'e (2011) göre madde toplam korelasyonu .30 ve daha yüksek maddeler bireyleri daha iyi ayırt etmektedir.

Tüm maddelerin ayırt edicilik indekslerinin belirlenmesi için yapılan bağımsız grup t-testi sonuçları ve madde korelasyonları Tablo 6'da verilmiştir.

Tablo 6. Alt \%27 ile Üst \% 27'lik Grubun t Testi Sonuçları ve Korelasyonları

\begin{tabular}{|c|c|c|c|c|c|c|}
\hline Maddeler & & $x$ & SS & $\mathrm{P}$ & T Puanı & $\begin{array}{l}\text { Madde } \\
\text { Toplam }\end{array}$ \\
\hline \multirow{2}{*}{ S65 } & ÜST \%27 & 4,985714 & 0,119523 & ,000 & \multirow{2}{*}{14,450360} & \multirow{2}{*}{,725 } \\
\hline & ALT \%27 & 2,742857 & 1,293078 & ,000 & & \\
\hline \multirow{2}{*}{ S67 } & ÜST \%27 & 4,971429 & 0,239046 & ,000 & \multirow{2}{*}{9,812664} & \multirow{2}{*}{,690 } \\
\hline & ALT \%27 & 3,328571 & 1,380206 & ,000 & & \\
\hline \multirow{2}{*}{ S52 } & ÜST \%27 & 4,943275 & 0,125872 & ,000 & \multirow{2}{*}{9,861383} & \multirow{2}{*}{,698 } \\
\hline & ALT \%27 & 3,434286 & 1,328384 & ,000 & & \\
\hline \multirow{2}{*}{ S39 } & ÜST \%27 & 4,971429 & 0,167802 & ,000 & \multirow{2}{*}{13,278506} & \multirow{2}{*}{,712 } \\
\hline & ALT \%27 & 3,014286 & 1,221698 & ,000 & & \\
\hline S60 & ÜST \%27 & 4,900000 & 0,514993 & ,000 & 14,003057 & ,727 \\
\hline
\end{tabular}


“Öğretmenlerin İletişim Becerilerini Değerlendirme Ölçeği” Geliştirme Çalışması

\begin{tabular}{|c|c|c|c|c|c|c|}
\hline & ALT \%27 & 2,728571 & 1,190803 & ,000 & & \\
\hline \multirow{2}{*}{ S56 } & ÜST \%27 & 4,942857 & 0,478091 & ,000 & \multirow{2}{*}{14,638032} & \multirow{2}{*}{,666 } \\
\hline & ALT \%27 & 2,900000 & 1,065262 & ,000 & & \\
\hline \multirow{2}{*}{ S1 } & ÜST \%27 & 4,871429 & 0,377690 & ,000 & \multirow{2}{*}{10,085185} & \multirow{2}{*}{,658 } \\
\hline & ALT \%27 & 3,414286 & 1,148318 & ,000 & & \\
\hline \multirow{2}{*}{ S3 } & ÜST \%27 & 4,891429 & 0,307747 & ,000 & \multirow{2}{*}{9,665014} & \multirow{2}{*}{,646 } \\
\hline & ALT \%27 & 3,642857 & 1,036098 & ,000 & & \\
\hline \multirow{2}{*}{ S5 } & ÜST \%27 & 4,628571 & 0,684644 &, 000 & \multirow{2}{*}{11,106017} & \multirow{2}{*}{,634 } \\
\hline & ALT \%27 & 2,600000 & 1,366260 & , 000 & & \\
\hline \multirow{2}{*}{ S15 } & ÜST \%27 & 4,943241 & 0,324873 & ,000 & \multirow{2}{*}{9,618513} & \multirow{2}{*}{ 711 } \\
\hline & ALT \%27 & 3,621429 & 1,199141 & ,000 & & \\
\hline \multirow{2}{*}{ S27 } & ÜST \%27 & 4,971429 & 0,167802 & ,000 & \multirow{2}{*}{10,493764} & \multirow{2}{*}{,574 } \\
\hline & ALT \%27 & 3,371429 & 1,264584 & ,000 & & \\
\hline \multirow{2}{*}{ S13 } & ÜST \%27 & 4,885714 & 0,400827 & ,000 & \multirow{2}{*}{11,990313} & \multirow{2}{*}{,585 } \\
\hline & ALT \%27 & 2,914286 & 1,315932 & ,000 & & \\
\hline \multirow{2}{*}{ S31 } & ÜST \%27 & 4,914286 & 0,329376 & ,000 & \multirow{2}{*}{9,913093} & \multirow{2}{*}{,560 } \\
\hline & ALT \%27 & 3,100000 & 1,495404 & , 000 & & \\
\hline \multirow{2}{*}{ S41 } & ÜST \%27 & 4,814286 & 0,728167 & ,000 & \multirow{2}{*}{9,876266} & \multirow{2}{*}{,503 } \\
\hline & ALT \%27 & 2,985714 & 1,367245 & ,000 & & \\
\hline \multirow{2}{*}{ S28 } & ÜST \%27 & 4,542857 & 0,845889 & ,000 & \multirow{2}{*}{9,579941} & \multirow{2}{*}{,463 } \\
\hline & ALT \%27 & 2,657143 & 1,413042 & ,000 & & \\
\hline & ÜST \%27 & 4,771429 & 0,515595 & ,000 & & \\
\hline S33 & ALT \%27 & 2,457143 & 1,410989 & ,000 & 12,889210 & 612 \\
\hline & ÜST \%27 & 4,857143 & 0,426843 & ,000 & & \\
\hline $3 / 2$ & ALT \%27 & 3,000000 & 1,434563 & ,000 & 10,381360 & 544 \\
\hline & ÜST \%27 & 4,871429 & 0,337142 & ,000 & & \\
\hline 563 & ALT \%27 & 3,085714 & 1,326900 & ,000 & 10,912853 & ,580 \\
\hline & ÜST \%27 & 4,900000 & 0,386362 & ,000 & & \\
\hline 345 & ALT \%27 & 3,257143 & 1,585128 &, 000 & 8,424664 & (563 \\
\hline S11 & ÜST \%27 & 4,757143 & 0,668889 & ,000 & & \\
\hline SII & ALT \%27 & 3,457143 & 1,369287 & ,000 & /,13/195 & ,433 \\
\hline
\end{tabular}

$\eta=259 \eta 1=\eta=70 p<0.01$

Tablo 7. Alt \%27 ile Üst \% 27'lik Grubun Faktörlere göre t Testi Sonuçları ve Korelasyonları

\begin{tabular}{|c|c|c|c|c|c|c|}
\hline Alt Boyutlar & & $x$ & SS & $\mathrm{P}$ & T Puanı & $\begin{array}{l}\text { Madde } \\
\text { Toplam }\end{array}$ \\
\hline \multirow{2}{*}{ 1. Alt Boyut } & ÜST \%27 & 29,771429 & 0,745449 &, 000 & \multirow{2}{*}{19,870470} & \multirow{2}{*}{,893 } \\
\hline & ALT \%27 & 18,148571 & 4,836778 & ,000 & & \\
\hline \multirow{2}{*}{ 2. Alt Boyut } & ÜST \%27 & 29,248571 & 0,239046 & ,000 & \multirow{2}{*}{17,353577} & \multirow{2}{*}{,856 } \\
\hline & ALT \%27 & 19,564286 & 4,547592 & ,000 & & \\
\hline \multirow{2}{*}{ 3. Alt Boyut } & ÜST $\% 27$ & 19,042857 & 1,301456 & ,000 & \multirow{2}{*}{15,669039} & \multirow{2}{*}{,716 } \\
\hline & ALT \%27 & 11,200000 & 3,980387 & ,000 & & \\
\hline \multirow{2}{*}{ 4. Alt Boyut } & ÜST $\% 27$ & 19,385714 & 0,952386 & ,000 & \multirow{2}{*}{12,375633} & \multirow{2}{*}{,710 } \\
\hline & ALT \%27 & 12,800000 & 4,349246 & ,000 & & \\
\hline
\end{tabular}

$\eta=259 \eta 1=\eta=70 p<0.01$ 
Tablo 6 ve 7'de görüldüğü üzere ölçekte bulunan maddelerin ve alt grupların ayırt ediciliklerini belirlemek üzere üst \%27 ve alt \%27'lik grupların aritmetik ortalamaları arasında anlamlı bir fark olup olmadığının belirlenmesi için yapılan bağımsız $t$ testi sonucunda tüm maddeler ve alt gruplar için farklılıklar istatistiksel olarak anlamlı bulunmuştur ( $p<.001)$. Bu farklılıklar üst\%27'lik grup lehine gerçekleşmiştir. Elde edilen sonuçlara baktığımızda tüm maddeler ölçtükleri özellikleri ayırt edici olduğu söylenebilmektedir. Yani bu durum ölçeğin, düşük puan alan katılımcılarla yüksek puan alan katılımcıları ayırabildiğini göstermektedir.

Ayrıca ölçekte bulunan maddelerin ve alt grupların madde toplam korelasyonuna baktığımızda tüm maddelerin korelasyonlarının anlamlı olduğu görülmektedir. Ayrıca bütün maddelerde pozitif korelasyon görülmektedir. Elde edilen bu sonuçlar maddelerin aynı yapı içerisinde olduğunu göstermektedir.

Tablo 6. Alt Boyutlar Arasındaki Korelasyon

\begin{tabular}{|l|l|l|l|l|l|l|l|}
\hline Alt Boyutlar & X & SS & Toplam & 1. Boyut & 2. Boyut & 3. Boyut & 4. Boyut \\
\hline 1. Alt Boyut & 4,168726 & 0,925413 &, 893 & 1 & & & \\
\hline 2. Alt Boyut & 4,211197 & 0,795674 &, 856 &, 705 & 1 & & \\
\hline 3. Alt Boyut & 3,906371 & 1,025200 &, 716 &, 528 &, 481 & 1 & \\
\hline 4. Alt Boyut & 4,048456 & 0,947008 &, 710 &, 533 &, 503 &, 310 & 1 \\
\hline
\end{tabular}

Ölçek alt boyutlar arasındaki ilişkinin saptanması için Pearson momentler çarpım korelâsyon analizi yapılmıştır. Analiz sonucuna göre alt boyutlar arasında pozitif yönde anlamlı bir ilişki olduğu görülmektedir. Alt boyutlar arasındaki en yüksek ilişkinin "empati ve yardım becerileri” alt boyutu ile "iletişim ortamı oluşturma" alt boyutları arasında olduğu görülmektedir ( $r=.705 ; p<.001)$. En düşük ilişkinin ise "sınıf yönetimi" alt boyutu ile "iletişim engelleri" alt boyutları arasında olduğu görülmektedir ( $r=.310 ; p<.001)$.

\section{Sonuç ve Tartışma}

Öğretmenlerin iletişim becerilerini değerlendirecek bir ölçek geliştirme amacıyla yapılan çalışmada öncelikle öğretmen iletişim becerileriyle ilgili alan yazın taranmış daha sonra uzman görüşlerine başvurularak madde havuzu oluşturulmuştur. Bu maddeler Konya merkezde ilköğretim ve ortaöğretimde öğrenim gören 259 öğrenci üzerinde uygulanmıştır. Öğrencilerden bir önceki dersi veren öğretmenlerinin iletişim becerilerini değerlendirmeleri istenmiştir. Oluşturulan madde havuzu gerekli analizler yapıldıktan sonra 4 alt boyut ve toplam 20 maddelik bir ölçek haline getirilmiştir. $\mathrm{Bu}$ alt boyutlar "empati ve yardım becerileri", "iletişim ortamı oluşturma", "sınıf yönetimi" ve "iletişim engelleri" 'dir. Maddelerin 12'si olumlu 8'i ise olumsuz yargıdan oluşmaktadır. Ölçeğin toplam Cronbach $\alpha$ değeri .908'dir. Alt boyutların Cronbach $\alpha$ değeri ise empati ve yardım becerileri 
boyutunda .875 , iletişim ortamı oluşturma boyutunda .819 , sınıf yönetimi boyutunda .734 ve iletişim engelleri boyutunda.${ }^{736}$ 'dır. Alan yazında öğrenmenin gerçekleştiği ortamı değerlendiren ölçeklerden biri olarak Tenenbaum, Naidu, Jegede ve Austin'in (2001) geliştirdiği yapılandırmacı öğrenme ortamı ölçeği örnek olarak verilebilir. Benzer şekilde Arkün ve Aşkar'ın (2010) geliştirdiği yapılandırmacı öğrenme ortamlarını değerlendirme ölçeği de öğrenci merkezli, düşündüren, işbirlikli, yaşamla ilgili, öğretim ve değerlendirmenin bir aradalığı ile farklı bakış açıları kazandıran olmak üzere altı faktör üzerine kurulmuş ve ölçeğin Cronbach Alfa katsayısının .96 olduğu belirlenmiştir. Aydın, Derelioğlu ve Palut (2001) tarafından geliştirilen "Sosyal Beceri Değerlendirme Ölçeği" ise kişilerarası ilişkiler, kendini kontrol ve empati olarak isimlendirilen üç alt boyuttan oluşmakta, ölçeğin genel Cronbach Alfa korelasyon katsayısı .81; birinci faktörün 0.79, ikinci faktörün 0.72, üçüncü faktörün de 0.71 ; test-tekrar test güvenirlik korelasyon katsayısı ise 0.89 olarak hesaplanmıştır.

Ölçekte yapılan analizlerde SPSS 21 programı kullanılmıştır. Analiz sonuçlarına göre KMO (Kaiser-Meyer-Olkin) değeri .922, Barlett Testi ise $\left(X^{2}=2.177, p<.000\right)$ anlamlı bulunmuş ve bu sonuçlara göre veri grubumuzun açımlayıcı faktör analizi yapmak için uygun olduğu sonucuna varılmıştır. Açımlayıcı faktör analiz sonucunda 20 maddelik ve 4 alt boyuttan oluşan bir ölçek elde edilmiştir. Karagöz ve Kösterelioğlu (2008) tarafından geliştirilen öğretim elemanlarının iletişim becerileri değerlendirme ölçeği "saygı, ifade becerisi, değer, engeller, motivasyon ve demokratik tutum" olarak ifade edilen altı alt boyuttan oluşmaktadır ve KMO değeri 0,881 olarak bulunmuştur.

Açımlayıcı faktör analizinden sonra (AFA) elde edilen 4 alt boyutlu yapı birinci düzey doğrulayıcı faktör analizi (DFA) ile test edilmiştir. Şekil 1 de verilmiş olan birinci düzey DFA sonuçlarına baktığımızda ki-kare 248.762, serbestlik derecesi, $164 \quad(p=.00)$, ki-kare/serbestlik derecesi= 1.517, uyum iyiliği indeksi GFI ,915, karşılaştırmalı uyum indeksi CFI .959, düzeltilmiş uyum indeksi AGFI .891, yaklaşık hataların ortalama karekökü RMSEA .45 ve standarize edilmiş kalıntıların ortalama karekökü SRMR .45 olarak bulunmuştur. Daha sonra 2. düzey faktör analizi yapılmıştır. Şekil 2'de verilen ikinci düzey doğrulayıcı faktör analizi sonuçlarına göre ki-kare, 284,858, serbestlik derecesi 169, $(p=.00)$, ki-kare/serbestlik derecesi= 1.686, GFI=.902 CFI= .944 AGFI=.876 RMSEA $=.52$ SRMR=.609 olarak bulunmuştur. Genel olarak sonuçlara bakıldığında uyum iyiliklerinin oldukça iyi ve kabul edilebilir düzeyde olduğu ve böylece ölçeğin geçerli olduğu sonucuna varılmıştır. Şahin'in (2007) iletişim becerileri ile çatışma yönetimi konularını ilişkisel olarak incelediği araştırmada, iletişim becerilerinin çatışma yönetiminde çok önemli bir yordayıcı olduğu sonucuna ulaşılış̧tır. Bu bağlamda geliştirilen bu ölçekle öğretmenlerin iletişim becerilerinin değerlendirilerek iletişim becerilerinin gelişiminde gerekli adımların atılmasıyla sınıf içinde yaşanabilecek çatışmaların önüne geçilebileceği ifade edilebilir. 
Ölçeğin güvenilir olup olmadığına bakmak için Spearman Brown, Guttman Split-Half ve Cronbach $\alpha$ (iç tutarlık katsayısı) değerleri hesaplanmıştır. Spearman Brown formülüyle hesaplanan iki yarı test güvenirliği .923 ve Guttman Split-Half tekniği kullanılarak yapılan iki yarı test güvenirliği de .847 olarak hesaplanmıştır. Cronbach $\alpha$ değeri (iç tutarlık katsayısı) ise ölçeğin toplamı için .908 olarak hesaplanmıştır. Bu sonuçlara göre ölçeğin iki yarı test güvenirliğinin de Cronbach $\alpha$ (iç tutarlık katsayısı) değerlerinin de yüksek olduğu görülmektedir. Ersanlı ve Balcı'nın (1998) geliştirdikleri Iletişim Becerileri Envanteri'nde, iletişim beceri düzeyleri davranışsal, bilişsel ve duygusal boyutlar olmak üzere üç faktördür. Güvenirlik analizlerinde ölçeğin alt boyutları ile genel toplam puanları arasında .73 ile .83 arasında korelasyon elde edilmiş; Cronbach alfa değeri .72, test tekrar test güvenirlik katsayısı ise .68 olarak bulunmuştur. Envanterin ölçüt geçerlik katsayısı .70 olarak hesaplanmıştır. Leonardi ve Barley (2011) örgütte normlar, değerler, rutin oluşturulması ve sürdürülmesi yoluyla örgütsel anlamlar oluşturarak kurumsallaşmanın oluşturulmasının iletişimle mümkün olduğunu belirtmiştir. Fidan ve Küçükali'nin (2014) ilköğretim kurumlarında yöneticilerin iletişim becerilerini inceledikleri araştırmalarında örgütsel değerlere ilişkin toplam varyansın \% 49'unun ilköğretim kurumlarındaki yöneticilerin iletişim becerileriyle açıklanabileceği sonucuna ulaşmışlardır. Bu bulgular özellikle okul ortamında iletişim becerilerinin önemini göstermektedir.

Alan yazında doğrudan öğretmenlerin iletişim becerilerini ölçen bir ölçeğin bulunmamasıyla birlikte mevcut diğer ölçekler ile karşılaştırıldığında geliştirilen “Öğretmen Iletişim Becerileri Değerlendirme Ölçeği”nin öğretmenlerin iletişim becerilerini değerlendirmede önemli bir araç olacağı düşünülmektedir.

\section{Kaynaklar}

Arkün, S. ve Aşkar, P. (2010). Yapılandırmacı öğrenme ortamlarını değerlendirme ölçeğinin geliştirilmesi. Hacettepe Üniversitesi Eğitim Fakültesi Dergisi, 39 (39), 32-43.

Aşkar, P. (1995). Geleceğin okulları. TED Ankara Koleji Vakfı Antalya Semineri Bildirileri (23-27 Ocak). Ankara.

Aydın, B., Derelioğlu.Y., \& Palut, B. (2001). Sosyal Beceri (IKE) Ölçeği geçerlilik ve güvenirlik çalışması. 6. Ulusal PDR Kongresi, Ankara ODTÜ.

Badea, L. \& Pana, N. A. (2010). The role of empathy in developing the leader's emotional intelligence. Theoretical and Applied Economics, 2 (543), 69-78.

Baker, S. B., \& Shaw, M. C. (1987). Improving counseling through primary prevention. Westerville: Merrill Publishing Company.

Baker, J. A. (2006). Contributions of teacher-child relationships to positive school adjustment during elementary school. Journal of school psychology, 44(3), 211-229.

Balcı, S. (1996). Danışma becerileri eğitiminin üniversite öğrencilerinin iletişim beceri düzeyine etkisi. Yayımlanmamış Doktora Tezi, On dokuz Mayıs Üniversitesi, Sosyal Bilimler Enstitüsü, Samsun.

Baumgartner, H., \& Homburg, C. (1996). Applications of structural equation modeling in marketing and consumer research: A review. International journal of Research in Marketing, 13(2), 139-161.

Bayram, N. (2013). Yapısal eşitlik modellemesine giriş. Amos uygulamaları. İstanbul: Ezgi Kitapevi. 
Bıçakçı, I. (2003). Iletişim ve halkla ilişkiler: Eleştirel bir yaklaşım. MediaCat Kitapları.

Büyüköztürk, Ş. (2002). Faktör analizi: Temel kavramlar ve ölçek geliştirmede kullanımı. Kuram ve uygulamada eğitim yönetimi, 32(32), 470-483.

Büyüköztürk, Ş., Çakmak, E.K., Akgün, Ö.E., Karadeniz, Ş., Demirel, F. (2010). Bilimsel araştırma yöntemleri. Ankara: Pegem Akademi.

Büyüköztürk, Ş. (2011). Sosyal bilimler için veri analizi el kitabı. Ankara: Pegem Akademi.

Celep, C. (1997). Öğretmenlik yeterlilik duygusu. Yaşadıkça Eğitim Dergisi, İstanbul, Ocak/Şubat.

Celep, C. (2002). Sınıf yönetimi ve disiplini. Ankara: Anı Yayıncılık.

Claus, C. J., Booth-Butterfield, M., \& Chory, R. M. (2012). The relationship between instructor misbehaviors and student antisocial behavioral alteration techniques: The roles of instructor attractiveness, humor, and relational closeness. Communication Education, 61(2), 161-183.

Cooper, B. (2002). Teachers as moral models? The role of empathy in teacher/pupil relationships. Yayımlanmamış Doktora Tezi, Leeds Metropolitan University.

Debasish, S.S. \& Das, B. (2009). Business communication. New Delhi: PHI Learning.

Demirel, Ö. (1995). Sınıf içi iletişim ve teknoloji. Antalya Semineri Bildirileri, 23-27 Ocak.

Dökmen, Ü. (1997). Illetişim çatışmaları ve empati. İstanbul: Sistem Yayıncılık.

Ergin, A., \& Birol, C. (2000). Eğitimde iletişim. Ankara: Anı Yayıncılık.

Engin, A. O., \& Aydın, S. (2007). Sınıf içi iletişimde öğretmenin rolü. Atatürk Üniversitesi Kazım Karabekir Eğitim Fakültesi Dergisi, (16), 1-14.

Erkuş, A. (2003). Psikometri üzerine yazılar. Ankara: Türk Psikologlar Derneği Yayınları.

Ersanlı, K. B. S., \& Balcı, S. (1998). Developing a communication skill inventory: Its validity and reliability. Turkish Psychological Counseling and Guidence Journal, 10(2), 7-12.

Fidan, M. \& Küçükali, R. (2014). Illköğretim kurumlarında yöneticilerin iletişim becerileri ve örgütsel değerler. Eğitim Bilimleri Araştırmaları Dergisi, 4(1), 317-334.

George, J. M., \& Jones, G. R. (1997). Organizational spontaneity in context. Human performance, 10(2), 153170.

Gibson, R. L. \& Mitchell, M. H. (1995). Introduction to counseling and guidance (4th ed.).Englewood Cliffs, NJ: Merrill/Prentice Hall.

Gordon, T. (1998). Etkili öğretmenlik eğitimi. (çev. Emel Aksay), İstanbul: Sistem Yayıncılık.

Güçlü, N. (2001). Iletişim. Ankara: Nobel Yayıncılık.

Gürsel, M. (2011). Sınıf yönetimi. Ankara: Eğitim Akademisi Yayınları.

Gürüz, D., \& Eğinli, A. T. (2008). Kişilerarası iletişim: bilgiler-etkiler-engeller. Ankara: Nobel Yayıncılık.

Hallinan, M. T. (2008). Teacher influences on students' attachment to school. Sociology of Education, 81(3), 271-283.

Hogan, R. (1969). Development of an empathy scale. Journal of consulting and clinical psychology, 33(3), 307316.

Karagöz, Y. \& Kösterelioğlu, İ. (2008). İletişim becerileri değerlendirme ölçeğinin faktör analizi metodu ile geliştirilmesi. Dumlupınar Üniversitesi Sosyal Bilimler Dergisi, 21, 81-98.

Kline, R. B. (2016). Principles and practice of structural equation modeling. New York: Guilford publications. 
Küçükahmet, L., Değirmencioğlu, Ç., Er, T., Öksüzoğlu, A.F., Özdemir, i.E, Korkmaz, A., (2000). Öğretmenlik mesleğine giriş. Ankara: Nobel Yayıncılık.

Leonardi, P. M., \& Barley, W. C. (2011). Materiality as Organizational Communication: Technology, Intention, and Delegation in the Production of Meaning. In T. Kuhn (Ed.), Matters of Communication: Political, Cultural, and Technological Challenges to Communication Theorizing (pp. 101-122). Cresskill, NJ: Hampton Press.

Mckay, M., Davis, M., \& Fanning, P. (2012). Iletişim becerileri (Çeviren: Özgür Gelbal). Ankara: HYB Basım Yayım.

O'Connor, E., \& McCartney, K. (2007). Examining teacher-child relationships and achievement as part of an ecological model of development. American Educational Research Journal, 44(2), 340-369.

Owen, F. K., \& Bugay, A. (2014). İletişim becerileri ölçeğinin geliştirilmesi: geçerlik ve güvenirlik çalışması. Mersin Üniversitesi Eğitim Fakültesi Dergisi, 10(2), 51-64.

Özgüven, İ, E. (1994). Uygulanan ders geçme ve kredi sistemine ilişkin öğretmen ve öğrencilerin görüşleri. Ankara: Psikolojik Danışma ve Rehberlik Derneği Yayını.

Pala, A. (2008). Öğretmen adaylarının empati kurma düzeyleri üzerine bir araştırma. Pamukkale Üniversitesi Eğitim Fakültesi Dergisi, 23(23), 13-23.

Podsakoff, P. M., MacKenzie, S. B., Moorman, R. H., \& Fetter, R. (1990). Transformational leader behaviors and their effects on followers' trust in leader, satisfaction, and organizational citizenship behaviors. The leadership quarterly, 1(2), 107-142.

Pollard, A. (2006). Reflective teaching (Second Edition). London,New York : Continuum.

Sönmez, V. (2003). Eğitimin tarihsel temelleri. Öğretmenlik mesleğine giriş, Ankara: Anı Yayıncılık.

Şahin, F. Y. (1998). Grupla iletişim becerileri eğitiminin üniversite öğrencilerinin iletişim beceri düzeylerine etkisi. Eğitim ve Bilim, 22(110), 12-19.

Şahin, A. (2007). illköğretim okulu yöneticilerinin kişiler arası iletişim becerileri ve çatışma yönetimi stratejileri arasındaki ilişki. Yayınlanmamış Yüksek Lisans Tezi. Akdeniz Üniversitesi Sosyal Bilimler Enstitüsü, Antalya.

Şimşek, Ö. F. (2007). Yapısal eşitlik modellemesine giriş: Temel ilkeler ve Lisrel uygulamaları. Ankara: Ekinoks.

Şimşek, Y. (2003). Okul müdürlerinin iletişim becerileri ile okul kültürü arasındaki ilişki. Yayınlanmamış doktora tezi. Anadolu Üniversitesi Eğitim Bilimleri Enstitüsü, Eskişehir, Türkiye.

Tenenbaum, G., Naidu, S., Jegede, O., \& Austin, J. (2001). Constructivist pedagogy in conventional on-campus and distance learning practice: An exploratory investigation. Learning and instruction, 11(2), 87-111.

Topluer, A. (2008). İlköğretim okulu yöneticilerinin iletişim yeterlilikleri ile örgütsel çatışma düzeyleri arasındaki ilişki. Yayımlanmamış Yüksek Lisans Tezi. Inönü Üniversitesi, Sosyal Bilimler Enstitüsü, Malatya.

Wiemann, J. M. (1977). Explication and test of a model of communicative competence. Human communication research, 3(3), 195-213.

Yılmaz, M. K., Tutar, H. (2003). Genel iletişim kavramlar ve modeller. Ankara: Nobel Yayın Dağıtım.

Zillioğlu, M. (1993). Iletişim nedir?. İstanbul: Cem Yayınevi.

\section{Extended Abstract}

Introduction

Humans as social beings are continually in interaction with their environments. It is necessary for individuals to acquire effective speaking and listening skills in order to better express themselves in their environments and better understand and comment on things told by others. Acquiring these skills becomes more important for professions, such as teaching, in which it is necessary to be in continuous interaction with students. These skills are called "communication skills". 
Teachers' levels of using their knowledge and skills determine the effectiveness of education. Teachers having high-level communication skills may present their knowledge and skills effectively in learning environments. It is necessary for teachers to improve themselves in order to perform educational activities effectively in this regard. In addition, for teachers who continually interact with their environments, being able to express themselves and better understand what is told will increase the effectiveness of education.

Since there are not any scales directly measuring communication skills of teachers in the related literature, developing a "teachers' communication skills assessment scale" was purposed in this research. Determining the levels of communication skills of teachers by means of this scale and trying to improve their weaknesses are crucial in providing teachers with better communication skills.

Method

The research population consisted of students who were studying in primary and secondary education institutions in the center of Konya in 2016-2017 academic year. In this research, applying the scale to a total of 300 students who were selected using random sampling method was planned. 259 of the scales which returned after they were examined were found suitable for the analysis.

Among the students who participated in the research, $54,4 \%$ of them were male( $n=141), 45,6 \%$ of them were female( $n=118)$. Besides, $25,5 \%$ of the participants were studying in grade $5(n=66), 24,7 \%$ of them were studying in grade $6(n=64), 21,6 \%$ of them were studying in grade $7(n=56), 5 \%$ of them were studying in grade $8(n=13), 11,6 \%$ of them were studying in grade $9(n=30), 6,2 \%$ of them were studying in grade $10(n=16)$ and $5,4 \%$ of them were studying in grade $11(n=14)$. In the scale which was answered by the students, they were asked to evaluate their teachers teaching the previous lesson. In its initial state, the scale included 73 items.

The initial state of the scale which consisted of 73 items was applied to 259 students and its final state was formed by doing necessary analyses on the obtained data set.

The obtained scale consists of a total of 20 items. 12 of these items include positive, 8 of them involve negative judgments. The items including negative judgments are reverse-scored. The scale has been formed in 5-point likert type. It has been formed as 5-Always, 1- Never. In the scale, the lowest score that could be got is 20 , the highest score that could be obtained is 100 .

In order to provide content validity of the scale, the experts were asked to give their opinions. The constructed item pool was sent to the experts and their opinions related to the questions were asked. Opinions of two experts from Turkish Language Education and one expert from Education Sciences, three experts in total, were asked. Taking the opinions of the experts into account, 3 questions were removed from the item pool and 2 questions were combined into one question, and the scale got its final state.

First of all, the exploratory factor analysis was done, and then the confirmatory factor analysis was conducted in order to determine the construct validity of the scale. Determining the capacity of the scale to measure the required feature was purposed thus.

\section{Result and Discussion}

In the research which has been conducted to develop a scale that will assess communications skills of teachers, the literature related to the communication skills of teachers was scanned at first, and then opinions of the experts were asked and the item pool was constructed. These items were applied to 259 students who were studying in primary and secondary education institutions in the centre of Konya. The students were asked to evaluate the communication skills of the teachers who taught the previous lesson. After conducting the required analyses, the constructed item pool has become a scale including 4 sub-dimensions and 20 items in total. These sub-dimensions are "empathy and helping skills", "creating a communication environment", "classroom management" and "barriers to communication". 12 of the items include positive judgments, while 8 of them include negative judgments. The total Cronbach $\alpha$ value of the scale is .908. Cronbach $\alpha$ value of the sub-dimensions is .875 in the dimension of empathy and helping skills, .819 in the dimension of creating a communication environment,.734 in the dimension of classroom management and .736 in the dimension of barriers to communication.

In the analyses conducted on the scale, SPSS 21 program was used. According to the results of the analyses, KMO value was .922, Barlett Test was found meaningful, and depending on these results, it was concluded that our data set was suitable for the exploratory factor analysis. As a result of the exploratory factor analysis, a scale including 20 items and 4 sub-dimensions has been obtained.

Following the exploratory factor analysis, the obtained 4 sub-dimensioned structure was tested using the firstlevel confirmatory factor analysis. When the results of the first level CFA given in Figure 1 are taken into consideration, it is seen that chi square was found as 248.762 , the degree of freedom was found as $164(p=.00)$, chi square/degree of freedom was found as 1.517, goodness of fit index was found as GFI, 915, the comparative fit index was found as CFI .959, the adjusted fit index was found as AGFI .891, the root mean 
square error of approximation was found as RMSEA .45 and the standardized root mean square residual was found as SRMR .45. Afterwards the second-level factor analysis was conducted. According to the results of the second-level confirmatory factor analysis given in Figure 2, chi square was found as 284,858, the degree of freedom was found as 169 ( $p=.00)$, chi square/degree of freedom was 1.686, GFI was .902, CFI was .944, AGFI was .876, RMSEA was .52 and SRMR was .609. When the results are examined in general, it has been concluded that goodness of fit is quite good and it is at an acceptable level, and therefore the scale is valid.

In order to see whether the scale is reliable or not, the values of Spearman Brown, Guttman Split-Half and Cronbach $\alpha$ were calculated. The split-half test reliability which was calculated by using Spearman Brown formula was .923 and the split-half test reliability calculated by using Guttman Split-Half technique was .847 . Cronbach $\alpha$ value was found as .908 for the whole scale. Depending on these results, it is seen that the value of split-half test reliability and the value of Cronbach $\alpha$ are considerably high. In the reliability analyses, a correlation ranging from .73 and .83 was obtained between the sub-dimensions and general total scores of the scale; Cronbach alpha value was found as .72 and test re-test reliability coefficient was found as .68. The benchmark reliability coefficient of the inventory was calculated as .70. Along with the fact that there are not any scales which directly measures communication skills of teachers in the literature, it is thought that "Teachers' Communication Skills Assessment Scale "will be a significant instrument to assess communication skills of teachers when it is compared with other current scales. 